\title{
IN SEARCH OF THE SOCIAL ÉLITE IN THE CORINTHIAN CHURCH
}

\author{
David W.J. Gill
}

\section{Summary}

As the Corinthian correspondence is read against the cultural background of a Roman colony, it is possible to identify members of the social élite within the church. After a consideration of the nature of the city and its élite, various case studies are presented. These include issues such as law courts, head-dresses, divisions at the Lord's Supper, households and dining. Through the issue of benefactions further light is thrown on Corinth's place in the province of Achaia and an estimate is made for the city's population.

\section{Introduction}

It was the Younger Pliny writing to the emperor Trajan in c. 110 who noted that among the Christians of Pontus there were people of 'every rank, age and sex'. ${ }^{1}$ However can such a statement by an influential figure such as Pliny be applied to the early years of the church? Certainly by the third century it is common to hear of Christians holding high civic status. ${ }^{2}$ This paper will try to address the status of Christians in the first century A.D., and it will draw on material from the Roman colony of Corinth which was almost certainly the seat of the governor of the Roman province of Achaia. ${ }^{3}$ Such a line of enquiry is part of one pursued by a wider Cambridge-based group of scholars. These include Andrew Clarke 4 and Bruce Winter. ${ }^{5}$

\footnotetext{
1 Pliny Ep. 10.96.
}

2See, for example, R. Lane Fox, Pagans and Christians (Harmondsworth, Penguin 1988) 294.

${ }^{3}$ Some of the issues will be discussed in greater detail in D.W.J. Gill \& B.W. Winter, A Cultural Commentary on the Corinthian Correspondence (London, Yale University Press, in preparation). See also D.W.J. Gill, 'Achaia', in D.W.J. Gill \& C. Gempf (eds.), The Book of Acts in its GraecoRoman Setting (Grand Rapids, Eerdmans, in preparation).

${ }^{4}$ A.D. Clarke, 'Another Corinthian Erastus inscription', TynB 42 (1991) 146-51; idem., Secular and Christian Leadership in Corinth: $a$ socio-historical and exegetical study of 1 Corinthians 1-6 (Leiden, E.J. Brill 1993).

${ }^{5} \mathrm{~B}$.W. Winter, 'The public honouring of Christian benefactors. Romans 13:3-4 and 1 Peter 2:14-15', JSNT 34 (1988) 87-103; 'Secular and Christian 


\section{Ancient Historians and their view of the status of Christians}

Although there has been a tendency in recent years for students of the New Testament to acknowledge the presence of members of the social élite in the early church, 6 this does not appear to be the case for those approaching from the historian's position. ${ }^{7}$ First let us turn to Robin Lane Fox's discussion on the status of Christian converts in his chapter on 'The spread of Christianity' in his Pagans and Christians. ${ }^{8}$ Attention is drawn to the low status of the converts. When Paul urges people 'not to steal', 9 Fox interprets this as being addressed to slaves and people who would normally steal. He emphasises the 'deep, abysmal poverty' of the Christians in Macedonia. ${ }^{10}$ At Rome, those who are 'in Caesar's household' are taken to be slaves. ${ }^{11}$ Women such as Phoebe, a deaconess in the church at Cenchreae 12 and Lydia from Thyatira ${ }^{13}$ are seen as ranking 'far below the civic, let alone the Imperial, aristocracies'.14

Yet Fox's assumptions about status are not always correct. In Romans 16:23 Paul mentions an Erastus who was the oikovó $\mu$ os of the Roman colony at Corinth. Fox takes this to mean that an oikovó

responses to Corinthian famines', TynB 40 (1989) 86-106; 'Theological and ethical responses to religious pluralism: 1 Corinthians 8-10', TynB 41 (1990) 209-26; 'Civil litigation in secular Corinth and the church: the forensic background to 1 Corinthians 6', NTS 37 (1991) 559-72.

${ }^{6} \mathrm{G}$. Theissen, The Social Setting of Pauline Christianity (Edinburgh, T. \& T. Clark 1982) esp. pp. 70-1. W. Meeks (The First Urban Christians: the Social World of the Apostle Paul [New Haven, Yale University Press 1983] 68) follows Theissen.

${ }^{7}$ Honourable exceptions would include, for example, E.A. Judge, 'The Early Christians as a Scholastic Community', Journal of Religious History 1 (1960) 8: 'Christianity was a movement sponsored by local patrons to their social dependents'. See also Meeks (pp. 51-53) for a discussion of the history of scholarship in this area.

8Fox, 293-312.

${ }^{9}$ Eph. 4:28.

102 Cor. 8:2.

11Phil. 4:22.

12Rom. 16:1.

${ }^{13}$ Acts $16: 14,40$.

14Fox, 293. See also Meeks (p. 51) for second century examples of how Christians were viewed. 
often held by a public slave' ${ }^{15} \mathrm{He}$ throws doubt on the link with the Erastus, the aedile of the colony, who dedicated a piazza adjoining the theatre in fulfilment of an election pledge. 16 The link between the two Erasti cannot be certain, especially as Paul does not give the praenomen and nomen of Erastus, and the inscription is damaged.17 However, it does seem likely from the available evidence that the Greek term 'oi кovó $\mu$ ○ was the equivalent of the Latin term aedile. Yet as has been argued elsewhere, why does Paul draw attention to the status of a man like Erastus if he was only a slave? ${ }^{18}$ Indeed, the fact that Paul gives emphasis to the civic status of Erastus may be to encourage other Christian members of the social élite to emulate him and take a full part in the life of their respective cities. If the Erastus of the inscription and of Paul are the same, then we would be wrong to give him servile status. However the lack of a patronymic in the inscription ${ }^{19}$ might suggest that Erastus was a freedman 'who had acquired considerable wealth in commercial activities' ${ }^{20}$

Yet Fox does allow some contact with the élite. ${ }^{21}$ At Athens Paul encounters Dionysius, a member of the Areopagus which was, in the Roman period, a council drawn from members of the élite. ${ }^{22}$ At Ephesus after the riots over Ephesian Artemis, Paul was encouraged not to go into the crowd; these included the 'Asiarchs' who were described as his friends ( $\phi \imath \lambda \circ i) .23$ This group, which consisted of ten elected magistrates, were drawn from the élite of the various cities of

15Fox, 293.

16D.W.J. Gill, 'Erastus the aedile', TynB 40 (1989) 293-301; see also A.D. Clarke, 'Another Corinthian Erastus inscription', TynB 42 (1991) 146-151; idem., Secular and Christian Leadership 46-56.

${ }^{17}$ See Theissen, 75-83, followed by Meeks, 58-9.

18Theissen, 76; 'an exceptional instance in which the worldly status of one member of the community is mentioned probably indicates status worth mentioning, that is, relatively high status'.

${ }^{19}$ There is not space for the letters.

20J.H. Kent, The Inscriptions, 1926-1950, Corinth 8.3 (Princeton (NJ), American School of Classical Studies at Athens 1966) no. 232.

21Fox, 293-4.

${ }^{22}$ Acts 17:34. For a summary of the arguments see Gill, 'Achaia'; T.D. Barnes, 'An apostle on trial', JTS 22 (1969) 407-19.

23Acts 19:31. 
the commune Asiae. ${ }^{24}$ Indeed Fox draws attention to the fact that subsequent to his meeting with Sergius Paulus, the governor of Cyprus, Paul travelled to the colony of Pisidian Antioch with which the governor had strong family ties. ${ }^{25}$ As Fox puts it, 'Christianity entered Roman Asia on advice from the highest society'. 26

It would be wrong to draw sole attention to Fox. Donald Engels in his Roman Corinth places emphasis on the lowly status of the Christians there. ${ }^{27}$ It should perhaps be noted that Engels has been influenced by Meeks. ${ }^{28}$ For example, Engels states that 'Paul was highly successful in making converts among the pagan, urban poor of the city'. ${ }^{29}$ Or again, 'the humble social origins of Christ would have attracted many of the city's working poor' ${ }^{30}$ Indeed, for Engels the social group who listened to Paul were not only poor, but they were Greek: 'the large audience for Paul's letters and sermons were mainly poor Greeks' ${ }^{31}$ For him this seems to reflect the reason why Paul 'experienced many difficulties with (the Corinthian Christians) he did not experience with converts in other cities'. ${ }^{32}$ Moreover, 'the urban working class. . found his (sc. Paul's) message attractive, not because it offered them something different, but because it was similar to their own religious beliefs; a complete break with their past religious

24R.A. Kearsley, 'Asiarchs, archieireis and the archiereiai of Asia', GRBS 27 (1986) 183-92. For the most recent view of Roman Asia Minor see S. Mitchell, Anatolia. Land, Men, and Gods in Asia Minor. Vol. 1: The Celts and the Impact of Roman Rule; Vol. 2: The Rise of the Church (Oxford, OUP 1993). ${ }^{25}$ Acts 13:7; S. Mitchell, 'Population and the land in Roman Galatia', in ANRW 7.2 (1980) 1073-4.

26Fox, 294.

27D. Engels, Roman Corinth: an Alternative Model for the Classical City (Chicago, University of Chicago Press 1990). For responses to Engels see A.J.S. Spawforth, ClRev 42.1 (1992) 119-20; R. Saller, ClassPhil 86.4 (1991) 351-7.

${ }^{28}$ Meeks, First Urban Christians. See the review by D. Kyrtatas, JRS 75 (1985) 265-7, esp. p. 267: '[Meeks] eliminates all attempts to present early Christianity as a proletarian movement, or, for that matter, as any kind of class movement'. For further observations in a review article: E.H. Pagels, 'Born Again', New York Review of Books 30,12 (1983) 41-3.

${ }^{29}$ Engels, 108.

30Engels, 114 .

31Engels, 70.

32Engels, 107. 
views was not necessary'.33 Indeed Engels hints that Paul had no right to apply notions of religious dogma and orthodoxy to this highly individual group. ${ }^{34}$

\section{The Roman nature of the city of Corinth}

In the following discussion of the Corinthian correspondence, I will take a position which holds that the letters are addressed to Roman citizens and deal with issues within the setting of a Roman colony. ${ }^{35}$ This is not to deny the other cultural groupings within the church. In Acts (18:2) Paul lived with the

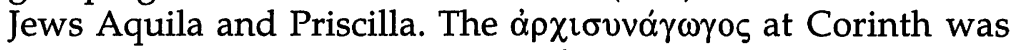
called Crispus (Acts 18:8). Yet we should note that all three had adopted Latin names which could have been used by any individual across the empire, Pagan, Jew or Christian; they had all taken on a mantle of Romanness. ${ }^{36}$ Some scholars have argued for a Greek presence in the colony and therefore Greek cultural interpretations for the epistles. Yet we do know that Greek families at Corinth also took on Roman names. For example, C. Julius Spartiaticus, a member of a prominent family at Sparta, set up an inscription in Latin at Corinth, but in Athens, Epidauros and Sparta, the same text was set up in Greek. ${ }^{37}$

The Romanness of the colony should not be underestimated. The city had a full Roman name, Colonia Laus Julia Corinthiensis. Its magistrates issued coinage with Latin

\footnotetext{
33Engels, 115.

${ }^{34}$ Engels, 111.

35This is dealt with in more detail in D.W.J. Gill, 'Corinth: a Roman colony in Achaea', BZ 37 (1993) 259-64. Not all scholars would agree that Corinth was Roman in character; e.g., W. Willis, 'Corinthusne deletus est?', BZ 35.2 (1991) 233-41. R.E. Oster's ('Use, misuse and neglect of archaeological evidence in some modern works on 1 Corinthians [1 Cor 7,1-5; 8,10; 11,216; 12,14-26]', ZNW 83 [1992] 52-73) comments may need some revision, especially with regard to continuity. Meeks (p. 47) claims that the depth of 'romanization' 'should not be exaggerated'; however, he seems to misunderstand the changes in Greece during the Hadrianic period. For further insights into first century A.D. Corinth see A.J.S. Spawforth, 'Corinth, Argos, and the imperial cult: Pseudo-Julian, Letters 198', Hesperia, forthcoming.

36Further on names at Corinth: Theissen, 94-6.

${ }^{37} \mathrm{D} . \mathrm{W} . J$. Gill, 'The Importance of Roman portraiture for head coverings in 1 Corinthians 11:2-16', TynB 41 (1990) 259.
} 
texts. Until the early second century A.D. public inscriptions were predominantly in Latin rather than Greek. The exceptions seem to be linked to the Isthmian games, ${ }^{38}$ one of the three most important religious and athletic events in Greece held every two years; alternate Isthmian games coincided with the Caesarean games. The architecture for the public buildings was Italian not Greek. Indeed, it has been argued that Temple E overlooking the Forum reflects the layout of the Forum of Augustus at Rome. Even the tombs of the social élite, such as that of Lucius Castricius Regulus, overlooking the harbour at Cenchreae, were more in keeping with Italian families. The individual's public career extended from c. 10 B.C. to A.D. 23, and he has been described as 'one of the richest Corinthians of his time' ${ }^{39}$ Likewise images of the emperor were in Roman guise. The portrait of Augustus showed him as an Italian magistrate with his toga placed over his head. This type is not found in the Greek city of Athens where more sympathetic styles of portraiture were set up. Taken together, we should, I would argue, seek to interpret the Corinthian correspondence against a background of Roman culture and values.

\section{The Social Élite at Corinth}

The Erastus of the theatre pavement inscription may have been a freedman. Yet such a background was not unusual among the social élite of the colony. Take for example $\mathrm{Cn}$. Babbius Philinus. He is known from inscriptions to have dedicated a monument at the west end of the forum ${ }^{40}$ and the south-east

38B.D. Meritt, Greek Inscriptions 1896-1927, Corinth 8.1 (Cambridge (Mass.), American School of Classical Studies 1931) no. 14 (A.D. 3, list of officials and victors at Isthmian games), no. 19 (Tiberius, victor's list), no. 70 (Nero ?, honorific base to $C$. Julius Spartiaticus). The inscriptions break down chronologically as follows:

$\begin{array}{llll}\text { Date } & \text { Greek } & \text { Latin } & \text { Total } \\ \text { Augustus-Trajan } & 4 & 99 & 103 \\ \text { Hadrian-Gallienus } & 35 & 17 & 52\end{array}$

${ }^{39}$ Kent, under no. 153.

40Kent, no. 155; West, Latin Inscriptions 1896-1926, Corinth 8.2 (Cambridge (Mass.), American School of Classical Studies 1931) no. 132.

(Cn Babbius Philinu)s aed pontif(ex)

(d s p f c iedmque) II Vir P

(Gaius Babbius Philinus), aedile and pontifex, (had this monument erected at his own expense), and he approved it in his official capacity as duovir. 
building, ${ }^{41}$ both under Tiberius. Indeed his presumed son, $\mathrm{Cn}$. Babbius Italicus, seems to have been involved with further work on the same south-east building. ${ }^{42}$ Despite the importance of this family it seems that Philinus was a freedman.

Some of the families at Corinth seem to have been members of the social élite of other cities in the province. Spawforth has noted the way that the colony attracted people to it and who went on to serve magistracies. One of the best known examples is the involvement of the Euryclid family from Sparta. This family rose to prominence in the late first century B.C. and continued into the second century A.D. 43 A fragmentary Augustan inscription refers to the gift of baths by Eurycles Herculanus. ${ }^{44}$ Indeed Pausanias (ii.3.5) refers to the Baths of Eurycles in the city although it is not certain that these are the same ones. The Augustan Eurycles was probably Gaius Julius Eurycles Herculanus who was born C. Julius Deximachos and adopted by C. Julius Eurycles sometime between 18 and 12 B.C. Indeed a later member of the family, C. Julius Spartiaticus, went on to be a magistrate at Corinth. 45

\section{The Social Élite and 1 Corinthians}

The problem of approaching the Corinthian correspondence is whether or not the issues which Paul addressed were liked by the social élite. It is noteworthy that at the beginning of 1 Corinthians Paul notes a church divided into separate groups, and that among the church there were some who were quite

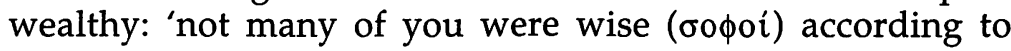

41West, no. 122; Kent, no. 323.

(Cn Babbius Philinus, II V)ir, pont(ifex, tabularium) et porticum coloni(ae (?) ---- (?) colo)nia.

42 Kent, no. 327.

${ }^{43}$ G.W. Bowersock, 'Eurycles of Sparta', JRS 51 (1961) 112-18. See also A.J.S. Spawforth, 'Families at Roman Sparta and Epidauros: some prosopographical notes', BSA 80 (1985) 191-258; P. Cartledge and A. Spawforth, Hellenistic and Roman Sparta: a Tale of Two Cities (London, Routledge 1989) 97-105.

${ }^{44}$ Kent, no. 314.

${ }^{45}$ Kent (p. 25) based on West, no. 68. For further information about the magistrates of the Roman colony see M. Amandry, Le Monnayage des duovirs corinthiens (BCH suppl. 15, Paris). 
worldly standards, not many were powerful ( $\delta v v \alpha \tau o i)$, not

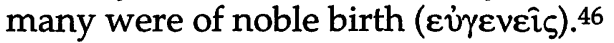

Given this background, it would be worth considering several sections in the Corinthian correspondence to see if they can be read against the background of social élites jostling for power in the church just as they would have done in the colony itself if we accept the Roman cultural norm.

\section{Law courts (1 Corinthians 6:1-8)}

The issue of not taking fellow Christians to court is one issue that should be discussed against the social background. ${ }^{47}$ Some have looked to the Jewish settlement of such cases. However,

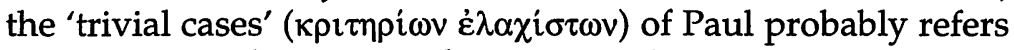
to civil rather than criminal cases, viz. claims concerning legal possession, breach of contract, damages, fraud and injury. Such cases could not be brought by people of lower rank or children, and thus it seems likely that Paul is referring to cases brought by members of the social élite against other élite families: the

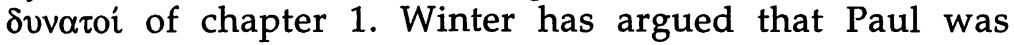
addressing the problem of magistrates and jurors who were $\dot{\alpha} \delta \imath \kappa o i$ (v. 1) and $\alpha \operatorname{t\imath \sigma \tau oi~(v.~6).~If~the~legal~system~could~be~}$ corrupted, then there could be no fair trial. A second point was that such cases could be brought to aggravate personal enmity by launching a personal attack on the character of one's opponents. 48 Indeed it was a time for young men from the élite families to demonstrate their forensic skills and put their oratorical training into practice. If there was rivalry between households in the Corinthian church-as reflected in chapter 1 -then what better way for this to show itself than by launching civil actions against one's opponents. It is at this point that Paul asks: 'can it be that there is no man among you wise enough to decide between members of the brotherhood...?' (v. 5).

Yet Paul has noted that there were people called ooфoi in the congregation. ${ }^{49}$ Surely what Paul is doing is asking for those members of the élite to put their skills to use in the

461 Cor. 1:26. This point was emphasised by Theissen, 70-1.

47B.W. Winter, 'Civil litigation'.

${ }^{48}$ Kelly (1976) 98.

491 Cor. 1:20, 26, 3:18. 
church as arbitrators rather than by increasing enmity within the church by pressing legal cases.

\section{Head Dresses (1 Corinthians 11:2-16)}

Paul urges men in the church not to wear head coverings when they come into the $\dot{\varepsilon} \kappa \kappa \lambda \eta \sigma i \alpha$. On the other hand women are to cover their heads in the assembly. The norm in Roman worship was for members of the social élite to cover their heads when coming to offer sacrifice, the so-called capite velato. 50 What he seems to be suggesting is that members of the social élite who were also members of the church were adopting pagan forms of dress for worship. At Corinth it is clear from inscriptions that the élite were fulfilling such priesthoods and indeed were honoured by the city for it. 51 Thus the élite would be recognisable by the fact that in the worship they would be the ones with their heads covered; they would be the ones who could pray. As a result the non-élite could not pray in the $\varepsilon \kappa \kappa \lambda \eta \sigma i \alpha$ and thus were excluded because of their status. Paul therefore re-emphasises that forms of worship must not be adopted which are exclusive; worship was open for all.

Such an approach by the élite is understandable. The colony was relatively new (less than 100 years old) and as a result it was very fashionable to adopt Roman styles in all aspects of civic life as we have seen. Thus, if, as Spawforth has argued, Corinth was the centre of Romanitas in Greece, 52 then the church too would be trying to express itself in a Roman rather than Greek or Jewish way. Such cultural 'snobbery' is perhaps hinted at in chapter 1 (v. 17) when Paul says that he did not bring the gospel with words of wisdom 'lest the cross of Christ be emptied of its power'. The implication is that members of the élite were expecting him to preach in an acceptable rhetorical style; when Paul did not, they were critical. Likewise in the church they may have been critical of non-Roman forms of worship.

The head coverings for women is again a cultural problem. There was no theological reason for women to

${ }^{50}$ This is seen, for example, on the Ara Pacis at Rome. Cf. Plutarch QuaestRom 266 D. For a discussion see Gill, 'Importance of Roman portraiture'.

${ }^{51 E . g . ~ K e n t, ~ n o . ~} 193$.

52A.J.S. Spawforth, in Cartledge \& Spawforth, op. cit., 104. 
uncover their heads in worship. Indeed women priests could be shown with their heads uncovered. However in the wider community the uncovering of the head by women hinted at dishonour. Thus people outside the church might think that female members of the church were devalued, especially those who were wives of men in public office. Therefore Paul advises the women to bow to cultural norms and cover their heads. Indeed such an interpretation is supported by Paul's command which is not to women in general but specifically to wives. In Roman Corinthian society it was commonplace for wives to honour their husbands, sometimes erecting elaborate honorific dedications, and Paul is suggesting that they do nothing to change this.

\section{Divisions at the Lord's Supper (1 Corinthians 11:17-21)}

The issue of division caused by dress is continued in the next few verses. Paul recognised that $\sigma \chi i \sigma \mu \alpha \tau \alpha$ became particularly apparent when the church met for the Lord's Supper. It has been argued by Alastair Campbell that the key group to whom

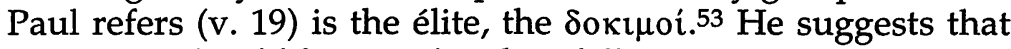
this verse should be translated as follows: 'For there actually has to be discrimination in your meetings, so that (if you please!) the élite may stand out from the rest'. In other words when the $\dot{\varepsilon} \kappa \kappa \lambda \eta \sigma i \alpha$ met the élite formed a distinct group arguing that they need not mix. In this way the élite stood apart from the rest.

\section{Christians as benefactors (1 Corinthians 11:17-33)}

There is a theme in Romans (13:3-4) and 1 Peter (2:14-15) to do good deeds. Winter has argued that this should be seen in the context of public benefactions by members of the social élites. ${ }^{4}$ This theme of benefactions appears in the Corinthian correspondence during the discussion of the Lord's Supper where it has been argued there is a background of food shortage. There seem to be two specific groups mentioned ( $v$. 21). The first, those for whom food and drink are plentiful and the second may be described as the 'have nots'. The epistle seems to have been written around the time of a famine-a

${ }^{53}$ R.A. Campbell, 'Does Paul acquiesce in divisions at the Lord's supper?', Novum Testamentum 33 (1991) 61-70.

54Winter, 'Secular and Christian responses'. 
time of food shortage-in the eastern Mediterranean. Garnsey has recorded various shortages which include Egypt and Boeotia, 55 and the Roman historian Tacitus specifically records A.D. 51 as a famine year. 56

If Paul was in Corinth in A.D. 51 it is likely that he either lived through a famine or one hit the city shortly after his departure. 57 There is a series of at least ten honorific inscriptions, perhaps supporting a statue, set up by the different tribes of Corinth to one Tiberius Claudius Dinippus. 58 $\mathrm{He}$ is recorded as holding the position of curator annonae three times. This man seems to have held the post of quinquennial duovir in A.D. 52/3. Thus it seems that in the A.D. 50s there was a food shortage which required a wealthy member of the city to hold this important role; and a role which he fulfilled so well that the citizens of the colony wished to honour him.

The scale of the problem of the food shortage at Corinth is suggested by the following figures. Although there is no ancient census recording the population of the colony, some attempts have been made to estimate it through the size of the settlement, the water supply, the size of public buildings (including the theatre), etc. Some years ago I proposed that Corinth and its territorium should have a population of no more than 100,000 people.59 More recently Engels has suggested figures of 80,000 for the colony and 20,000 for its territorium.60 It has been estimated that the average grain consumption per person per year in antiquity was in the region of $175 \mathrm{~kg} .61$ Using other statistics it has been calculated that 55

55P. Garnsey, Famine and Food Supply in the Graeco-Roman World (Cambridge, CUP 1988) 261.

56Tacitus 12.43.1.

${ }^{57}$ For a summary of the arguments see Gill, 'Achaia'.

58West, nos. 86-90; Kent, nos. 158-163. Dinippus was also military tribune of the Legion VI Hispanensis, and agonothete.

${ }^{59}$ In an unpublished lecture given at Tyndale House, Cambridge. This was based on city size. For a comparison of Corinth with other cities in the Roman province see S.E. Alcock, Graecia Capta: the Landscape of Roman Greece (Cambridge, CUP 1993) 162 fig. 56 (based on city perimeters).

${ }^{60}$ Engels, 84 . See also Alcock, 160, with p. 252, n. 45 . The parameters are 100 people/ha. and 160 people/ha.

${ }^{61}$ Garnsey, 99 . He has an upper figure of $230 \mathrm{~kg}$, and a minimum figure of $150 \mathrm{~kg}$. 
consumers could be fed by $1 \mathrm{~km}^{2} .62$ Using these figures and possible populations for Corinth, the following calculations are possible:

population

$\begin{array}{rr}100,000 & 17,500 \\ 80,000 & 14,000 \\ 70,000 & 12,250 \\ 60,000 & 10,500 \\ 50,000 & 8,750 \\ 40,000 & 7,000\end{array}$

grain (tonnes) land needed $\left(\mathrm{km}^{2}\right)$

1818

1455

1273

1091

909

727

The territorium of Corinth has been calculated as covering some $825 \mathrm{~km}^{2}$, of which only some $207 \mathrm{~km}^{2}$ is available for agriculture. ${ }^{63}$ Using Garnsey's consumption figures such land would only support some 11,385 people. ${ }^{64}$ It is quite clear that there would have been a need to import the vast majority of the food needs for this city, and that in times of shortage a large percentage of the population would suffer shortage.

The growing emphasis of field-survey in recent years has focused on the use of land. One of the current areas of discussion is the impact of urban centres such as Corinth on peripheral agricultural areas such as the southern Argolid.65 Yet even in this area with perhaps some $200 \mathrm{~km}^{2}$ there would not have been enough land to feed its own population, perhaps some 6,800 to 7,300 people, 66 and that of Corinth.

If Christian members of the élite were to be active in the church to ease the problems of famine, then how were they to do this? Although we do not know the names of members of the Christian élite at Corinth, and thus find the base for their wealth, it is possible to look at other Corinthian families. For example the Euryclids, who were great benefactors of the

62The upper figure is $42 \mathrm{~km}^{2}$, the lower $64 \mathrm{~km}^{2}$. Garnsey, 102, with reference to Table 7 .

${ }^{63}$ Engels, 27.

$64207 \mathrm{~km}^{2}$ × $55=11,385$ people. Engels (p. 27) estimates that some 17,600 could be supported as an absolute maximum; elsewhere (p. 29) he suggests the figure of 10,000 .

${ }^{65} \mathrm{Tj} . \mathrm{H}$. van Andel and C. Runnels, Beyond the Acropolis: a Rural Greek Past (Stanford, Stanford University Press 1987).

66 van Andel and Runnels, 174. The area need to grow the food for this population would $124-133 \mathrm{~km}^{2}$. 
Roman colony, came from Sparta. Their estates would almost certainly have grown grain as well as olives.

Another example would be Lucius Licinnius Anteros who was granted grazing rights on the peninsula of Methana in the Argolid.67 There seems to be a family tie with this polis as another member of the Licinnii was elected to the Panhellenion-a cultural grouping - in the second century A.D. If Anteros was indeed an absentee landlord, it may be possible to see him linked to the ownership of large flocks, and perhaps, by analogy with Hierapolis, the production of textiles. 68 This of course would not be to argue that members of the élite were directly involved in manufacture, but that they had enough money to invest in flocks which could then be used to generate wealth. Methana itself has been the scene of a major intensive field-survey by a team from the University of Liverpool in conjunction with the British School at Athens. This has revealed, for the first century A.D., a number of sites mainly in the area around the urban centre. ${ }^{69}$ Foxhall has argued from this evidence that some of the sites may indeed be agricultural sites belonging to the estates of absentee landlords, as only they would have the money to invest in the equipment for olive pressing. 70

The last two examples would suggest money from agriculture and livestock. However Pleket has argued that in the large harbour cities of the eastern Mediterranean, members of the social élites were involved with shipping. ${ }^{71}$ This is linked to the large risks undertaken by shipping and the élites would be in a position to finance enterprises. One such member of the Corinthian élite involved in this way may well have been L.

\footnotetext{
67IG IV,1, 853.

${ }^{68} \mathrm{H} . W$. Pleket, 'Urban elites and business in the Greek part of the Roman Empire', in P. Garnsey, K. Hopkins and C.R. Whittaker (eds.), Trade in the Ancient Economy (London, Chatto \& Windus 1983) 141-43.

${ }^{69}$ See C.B. Mee, D.W.J. Gill, H.A. Forbes and L. Foxhall, 'Rural settlement change in the Methana peninsula, Greece', in G. Barker and J. Lloyd (eds.), Roman Landscapes; Archaeological Survey in the Mediterranean Region (Archaeological Monographs of the British School at Rome 2, London 1991) 22332.

70L. Foxhall, 'The dependent tenant: landleasing and labour in Italy and Greece', Journal of Roman Studies 80 (1990) 97-114.

71Pleket, 138: 'the estate-owning urban elite in harbour cities of some size and importance were involved indirectly in trade as shipowners'.
} 
Castricius Regulus whose monumental tomb overlooked the harbour at Cenchreae. ${ }^{72}$ His offices listed on the tomb included aedile, quinquennial duovir, agonothete, benefactor of the sanctuary of Poseidon at Isthmia and entertainer of all the inhabitants of the colony at a meal, and these reflect the active public life that he led.73

Paul argued (vv. 33-4) that the Lord's Supper was not to be a time of feasting for some and not for others. If feasting was in his mind, he encouraged those with food to eat at home.

\section{Household of Stephanas (1 Corinthians 16:15)}

It is against this background of food shortage that we should probably understand the household (oiki $\alpha$ ) of Stephanas. This man and his household were commended for 'devoting themselves to the service of the saints'. There is a hint that Stephanas is a member of the élite as his household is mentioned.74 If he was like the Licinii or the Euryclids with estates outside the territorium of Corinth, or like the Castricii with links to shipping, then, he would have been in a position to meet the needs of the saints through the distribution of food.

\section{Invitations to dinner (1 Corinthians 10:27, 8:4-6)}

Dining in the Roman world tended to be restricted to the Roman élite. This is not to say that the poor were not given meals. For example Lucius Castricius Regulus was recorded on an inscription set up by his son to have given a banquet for all the inhabitants of the colony; ${ }^{75}$ presumably this was during some festival given that Regulus was an agonothete for several of the games. However Paul here does seem to be addressing a specific social group.

'If one of the unbelievers invites you to dinner and you are disposed to go, eat whatever is set before you without raising any question on the ground of conscience.' This was even when the food, probably meat, had previously been

72W.W. Cummer, 'A Roman tomb at Corinthian Kenchreai', Hesperia 40 (1971) 205-31.

73Kent, no. 153.

${ }^{74} \mathrm{Cf}$. Theissen, 87: (in connection with Stephanas) 'Reference to someone's house is hardly a sure criterion for that person's high social status; but it is a probable one, particularly if other criteria point in the same direction'.

75Kent, no. 153. 
offered as a sacrifice to the gods. A second issue of chapter 8 was actually attending pagan banquets, and the argument used by Corinthian Christians was that idols were not real. ${ }^{76}$

\section{Conclusion}

In this look at some of the evidence from the Corinthian correspondence it is becoming clear that there is an underlying thread of Paul interacting with members of the social élite at the colony who were also Christians. Other areas, such as contributions for the saints 77 or links with 'debaters of the age',78 might be further topics to explore in connection with euergetism and education respectively. I would suggest that Corinthian Christians were not encouraged to abandon their civic duties, but Paul did encourage them to put their gifts to

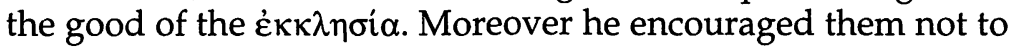
bring into the life of the church their cultural 'baggage' but to think through how the Christian message would affect their life as influential members of the Roman colony. It was Meeks himself who called for a greater interaction with the 'secular study of the Roman Empire 79 in order to understand how Christianity expressed itself within the context of the GraecoRoman city. It is at Corinth, with its wealth of epigraphic, archaeological and literary data, that the New Testament scholar can gain important insights into social stratification within the church. It is at Corinth that the élite can be found to have played an important role in the ekklesia. 80

\footnotetext{
76Winter, 'Theological and ethical responses'.

771 Cor. 16:1-4.

781 Cor. 1:20.

${ }^{79}$ Meeks, 1.

80I am grateful to members of the Early Christian and Jewish Studies seminar of the Divinity School, University of Cambridge, for their contributions and comments when this paper was given in 1992. Economic aspects had been presented to the 'Hellenistic and Roman Greece' and Laurence seminars in the Faculty of Classics, Cambridge.
} 